\title{
Battling the race: Stylizing language and coproducing whiteness and colouredness in a freestyle rap performance
}

\author{
Quentin E. Williams \& Christopher Stroud
}

\begin{abstract}
In the last 19 years of post-apartheid South African democracy, race remains an enduring and familiar trope, a point of certainty amid the messy ambiguities of transformation. In the present article, we explore the malleable, permeable, and unstable racializations of contemporary South Arica, specifically the way in which coloured and white racializations are negotiated and interactionally accomplished in the context of Capetonian hip-hop. The analysis reveals the complex ways in which racialized bodies are figured semiotically through reference to historical time and contemporary (translocal) social space. But also the way iconic features of blackness are reindexicalized to stand for a transnational whiteness.
\end{abstract}

\section{Introduction}

In the context of South Africa, the structural category of race remains a primary mold into which everyday interactions and identities are cast, providing an enduring and familiar trope, a point of certainty amid the messy ambiguities of post-apartheid transformation. Racial discourses couched as metaphors of racial harmony such as the "rainbow nation," the invocation of pan-African imaginaries of new communities of Ubuntu, and the crass practicalities of affirmative action and Black Economic Empowerment (BEE) dominate public debate and government legislation. Despite the perpetuity of race as a lived category, discourses of racialization, that is the words and ways through which people construct and navigate race on an everyday basis, are fluid, shifting and entangled: they are "a complicated multiplicity of identifications producing, reproducing and trans- forming identities under changing social and historical circumstances" (Walker 2005:41).

The purpose of this paper is precisely to explore some of the ways in which the malleable, permeable, and unstable racializations of contemporary South Africa are indexed and performed linguistically. We look at how people use language to position themselves and are positioned as racial subjects in order to examine the "forms of racialized subjectivity that are produced in different racialized forms of life" (Durrheim, Mtose, and Brown 2011:201). Specifically, we explore how forms of racial positioning in everyday interactions reproduce or contest the historical faultlines of hegemonic racial discourses of the apartheid state 20 years on. We do this by drawing on recent research on the indexicalities of race and language in the performance of popular culture and 
specifically the racialized linguistic and lyrical practices of emcees in a contemporary hip-hop milieu of Cape Town. We attend in particular to the concerted coproduction of multilingual freestyle battle lyrics, and to the complex ways in which racialized bodies are figured semiotically through reference to historical time and contemporary (translocal) social space. By way of conclusion, we tie this into the everyday ways in which race as an enduring presence and structural category, is negotiated in the contemporary (political) context of South Africa (Dolby 2001:8; cf. Durrheim et al. 2011), and more widely. In what follows, we provide a more detailed ethnography of performances of race in South African hip-hop, contextualized within a review of race, language, and hip-hop culture.

\section{Race, Language, and Hip-Hop in Cape Town Racial labels and categories}

Post-apartheid South Africa inherited a complex, shifting, and divisive system of racial classification at independence in 1994 that continues to seep into the minutiae of everyday life of the majority of South Africans, who remain divided by phenotype with its associated distinctions of place, space, and stereotypes of racial bodies and aesthetics. However, racializations are variable and unstable, and specific to geopolitical and historical context. In this paper, we focus on discourses of racialization around two such racial labels, namely the categories of "Coloured" and "White" (Adhikari 2005; Erasmus 2005; McCormick 2002). Coloured is an ethnonym created by the apartheid government to refer to those of predominantly mixed race who were not easily classified as either of the dominant categories, White or Black. Throughout apartheid (Erasmus 2001), it was a fraught identity category, and remains even more so today with some Coloured intellectuals and elites choosing to distance themselves from the label "Coloured," preferring the label "Black," while others are finding a new use for the label as a rallying call to a new sense of indigeneity-a "Coloured nation." As an "identity in crisis" in postapartheid South Africa, the term "Coloured" straddles "fragmentation, uncertainty, and confusion" (Adhikari 2005:6; cf. Alexander 2013), comprising a floating signifier, available to capture multiple positionings and stand proxy for a variety of social expression in ways similar to its construction in apartheid era of South Africa (Adhikari 2005:186; Adhikari 2006).

The category of whiteness is, not surprisingly, also one constituted through fraught and ambivalent discourses. Shome (2000) notes how "whiteness. . is not a monolithic formation-it is constantly made and remade through its participation in other unequal social relations; a nuanced formation that secures its power in different ways through different sites" (2000:368). In the South African context, English- and Afrikaansspeaking White South Africans have been "whitened" differently, both historically as well as today. Historically, Afrikaans-speaking Whites have lived a subaltern whiteness that has "remained prey to another dominant white discourse" (Gabriel 1998 quoted in Steyn 2004)-the English. Today, although both English- and Afrikaans-speaking Whites continue to share in the privilege, protection, and benefits of their "whiteness" across a range of societal areas, the way in which their "whiteness" is resourced differs significantly (Steyn 2004:144). For Afrikaners, "[i]ntersectionality, contradiction and hybridity are an integral part of Afrikaner selfhood" (2004:148), a condition that Steyn depicts as: 
Europe knotted into Africa, slave ancestry buried within white supremacist ideology, segregation along ambiguous, racially structured formations cleaved within a single linguistic community, unstable gluing together of with English speaking South Africans into white South Africanism, internal tensions "riven along ideological lines." (Steyn 2004:148-149)

South African English-speaking whiteness, on the other hand, feeds off its historical links to sites of geopolitical power and influence with global centers (such as the United Kingdom, United States, or Australia). South African English White identity is very much about "removing oneself" from the local site, by relying on the seamless recontextualization of old narratives of "native incompetence" and the "White man's burden." Complaints on the inefficiencies of service delivery, or the poor state of roads and other infrastructure in Black-run municipalities do not fail to elicit sympathetic acknowledgment of "white victimhood" from an international whiteness keyed into the familiar Afropessimism of global media news footage.

\section{Linguistic labels and categories}

This inward-outward looking orientation to whiteness distinguishing the two groups surfaces in an interesting parallelism with the multilingual variety of practices associated with English- and Afrikaans-speaking Whites and their associated language ideological discourses. With Afrikaans, the search for ethnic/racial purity has found resonance in language purism. Despite or perhaps because of its creole origins, Afrikaans has been stringently policed with White Afrikaans practices designated as "pure" Afrikaans or Standard Afrikaans, and contrasted with particular ideologically loaded named varieties closely tied to Coloured identity viewed as "distorted" speech, such as "Kitchen Afrikaans," Coloured people's parlance or patois, "Coloured language," "Coloured Afrikaans," "Capey" or "Gammat-taal" (Blignaut 2014:2; Small 1972). ${ }^{1}$

One form of speech that questions the legitimacy of the apartheid version of "Pure Afrikaans" and the derogatory labels for local speech practices of Afrikaans is "Gamtaal," a Cape Flats dialect of Afrikaans that "has stereotypically been associated with notions of the 'authentic' working-class coloured" (Haupt 2001:173). ${ }^{2}$ The label "Kaaps" also carries a resistant ideology created by Adam Small, the dramatist, poet, and novelist who wrote in this variety. Small argued that Kaaps is not what an English speaker in South Africa would consider as Capey or what certain Afrikaans people would call Gammattaal, but the mother-tongue of the Coloureds and Malays of Cape Town (Blignaut 2014:45; Hendricks 2012; Small 1972:99; Small 1987:83-84).

Local South African English, the variety traditionally largely spoken by White first language speakers of English in South Africa, developed as a hybrid mixture of Cape English, a koineized variety of English spoken by migrants "of lower class origin and predominantly from the south-eastern part of England (including London" (Bekker 2012:14), Natal English and "a gamut of other English accents (British as well as colonial) as well as L2 varieties such as the English spoken by L1-Afrikaans speakers and L1 Yiddish speakers" (Bekker 2012:141). Today, researchers recognize a variety of forms of English, such as Black South African English, South African Indian English (Mesthrie 1992), Cape 
Flats/Coloured English (McCormick 2002), stylects such as Tsotsitaal (Mesthrie 2008) and registers such as Sabela (Williams and Stroud 2010).

\section{Hip-Hop}

Besides language, racializations in rap performances are especially rich resources for the study of how space is racialized and reflected in localized styles of rap in the South African context. Hip-hop on the Cape Flats remains a space of contestation and continues to speak to the category of blackness as one of "heterogeneity and difference" (Watkins 2001:29). Warner (2011:118) argues that the Cape Flats is typically a "problem space" because of the historical classification and forced removals of Coloured people to the barren flatland, and therefore hip-hop spaces can be understood as normatively Black. Since 1994, new localized genres of global hip-hop 3 such as Spaza Rap (pioneered by Black Xhosa hip-hoppers in Black townships) and Zef Rap (pioneered by White Afrikaans hip-hoppers), have sought to grapple with contestations and coproductions of Blackness and Whiteness, respectively. In particular, studies on Zef rap performances took on board lyrical experimentation with new ways of doing whiteness, amid an assumed crises of power, masculinity, and sexuality among White Afrikaans youth (specifically), related to "unlearning" knowledges of apartheid orthodoxy and banality, and everyday pressures of relearning what it means to be White in a post-apartheid country. According to Marx and Milton (2011), Zef culture is reconfiguring Afrikaans whiteness in a deliberate attempt to speak "to the perceived sense of marginal and liminal experience of white Afrikaans youth in post-apartheid South Africa” (cf. Marx and Milton 2011:723). As a rap genre infused with White discursive practices, values, and virtues in the context of a historically Black genre, Zef allows "white artists, indulging in a category of performance marked as black, [to] challenge dominant stereotypes not only about white identity, but also about black identity, and in the process deconstruct seemingly fixed identities" (Marx and Milton 2011:737). This potentially opens up "a space for a generation [of White citizens] increasingly fed up with politics and the burden of being white and Afrikaans in post-apartheid South Africa to come out and explore what it means to be white in a context where politics are obscured and whiteness is marked, but not in the traditional discourse of white privilege vs black suffering" (Marx and Milton 2011:743).

Despite the present-day proliferation of rap groups, hip-hop remains a predominantly "coloured genre" with a thematics of urbanism, working class, violence, gang lore, and resistance that mimics the situation of Black hip-hop in the United States. The historically Coloured youth hip-hop groups like P.O.C (Prophets of Da City), Black Noise and Brasse vannie Kaap (BVK) (Brothers from the Cape) used Kaaps as early as the 1980 s and early 1990 s to speak out lyrically "over the monolithic way in which coloureds are represented in the mainstream media" (Haupt 2001:177), providing counterdiscourse to "conservative and essentialist readings of colouredness" (Haupt 2001:179; Haupt 1996:58). The rap groups themselves preferred the label of Gamtaal over Kaaps as better articulating their antihegemonic ideas and practices of resistance against apartheid and the essentializing of Coloured identity (Haupt 1995; Haupt 2001:179; Warner 2011:118; Watkins 2001:29). The importance of Gamtaal for engaging and mobilizing youth around political and economic issues comes across clearly in a quote from Shaheen, a member of POC, in an early interview with Haupt:

\section{https://repository.uwc.ac.za/}


When we do interviews and shit like that and we speak gamtaal, or whatever, that shit's on purpose so the kid at home can say, 'Fuck, they're speaking my language,' you know? They're representing, you know, what comes out of the township and shit. So if some middle class motherfucker comes, 'Oe God, skollietaal.' The shit's not for them, you know what I mean? I don't care if some white-ass dude at home thinks, 'Oh shit, look at this...uncultured, you know? I want some kid form the ghetto to think, 'Naa, we can relate to that.' (Haupt 1995)

The performance of lyrics in Gamtaal indexed these groups' counterdiscourses against racism, class marginalization, and monoglot language ideologies (Ariefdien and Burgess 2011:235) and served as a bridge to young Coloured speakers in the township. It continues to do so today. 4

The freestyle battle we analyze in this paper, recorded at the annual African Hip-Hop Indaba, articulates many of the organizing tropes of localized South African racial contestation discussed above. Freestyle rap battles as a performance genre are "active sites for the contestation and potential reorganization of social meanings and identities" (Alim, Lee, and Carris 2011:116; Cutler 2003, 2009). The genre allows emcees to draw on both local and transnational markets of identities. In these battles, racializations often figure centrally as "highly stylized" performances (Coupland 2009) to which extra attention is given, and which therefore "tend to be among the most memorable, repeatable, reflexively accessible forms of discourse" (Bauman 2005:149). The focus of this analysis is the negotiation and interactional accomplishment of Coloured and "White" in contexts of Capetonian hip-hop, and with it, the "expansion" and consolidation of English in all its varieties and the reinforcement of Gamtaal. Our analysis will illustrate ways in which contemporary racial discourses and their counterdiscourses are circulated, challenged, and ultimately reproduced in this particular genre of performance. It will show how race is read through tropes of gender, sexuality, and labor, as well as figured transnationally and transtemporally. The analysis also stresses the importance of linguistic biographies as they inform single moments of interaction; specifically, how they throw light on how contemporary discourses of race are maintained-even reinforced-in a form easily palatable to an audience. We argue that whiteness, rather than remaining an invisible vector for the White emcee, invokes privilege and claims to prowess. These are "outed" and challenged by the Coloured contestant who foregrounds the historically entangled identity of South African whiteness.

\section{The Race in the Battle: TaktikOne versus Ben10 5}

The data for this paper is taken from an annual hip-hop event taking place in Cape Town, comprising young male and female rappers with a range of rap styles, organized by the Heal the Hood, a South African nongovernmental organization working in community engagement. On the night of the Freestyle Battle Championship 2011, the organizers sported a long list of Coloured male emcees who would engage each other in lyrical confrontation for the coveted prize. ${ }^{6}$ The freestyle battle mediator for the night was the 2010 Freestyle Battle Champion, a Coloured emcee by the name of Hemelbesem. After a series of eliminations, two emcees made it to the final: TaktikOne and Ben1o. The first emcee represented Knysna, while his opponent, Ben10 represented Paarl Valley, two cities 
in the Western Cape, each with their distinct styles of hip-hop. The first round of their battle consisted of a freestyle performance with an accompanying beat selected by the deejay and evaluated by a panel of judges. This was followed by an a capella performance by both emcees, after which a "final round" between TaktikOne and Ben1o (which was encored and followed by yet another final round), culminated in the announcement of a winner. Unlike street or some stage lyrical battles (cf. Lee 2009; Williams and Stroud 2010), Hemelbesem-as battle mediator-chose which emcee would initiate the battle, introducing each emcee and the "style community" they represented.

The first emcee introduced on stage was TaktikOne, representing Knysna, a town in the Northern Cape of South Africa. On his Facebook page, he introduces himself not only as TaktikOne but as a UK-based performer, emcee, and lyricist. TaktikOne is in fact the stage name for Daniel Butler, a South African-born UK rapper. Butler is also Daniel "the Savage" Butler, the frontman for a band Four4One40, based in the United Kingdom with a range of styles and genres. TaktikOne is profiled on the band's page as a battle rapper and performance emcee with a dedication to lyricism and delivery that constantly placed him among the highest ranked emcees in his native South Africa. With over a decade behind the mic, he is a consummate freestyler as well as written work word smith. (www.babalas.net/biography/, accessed October 10, 2014) With this global exposure to hip-hop and doubling as a rapper/frontman of a dubstep, nu metal, soul funk band, TaktikOne presents himself as be deeply embedded in global hip-hop practices and performances. His hip-hop style is simultaneously local and global, with lyrics, cadence and flow that situate him in a hip-hop style community strongly influenced by New York East Coast hip-hop culture in the United States.

In the opening part of his freestyle battle, TaktikOne stylizes vernacular Englishes and Kaaps as he organizes his lyrics around familiar images and languages of global hip-hop: drinking champagne, celebrating success, and performing braggadocio: 


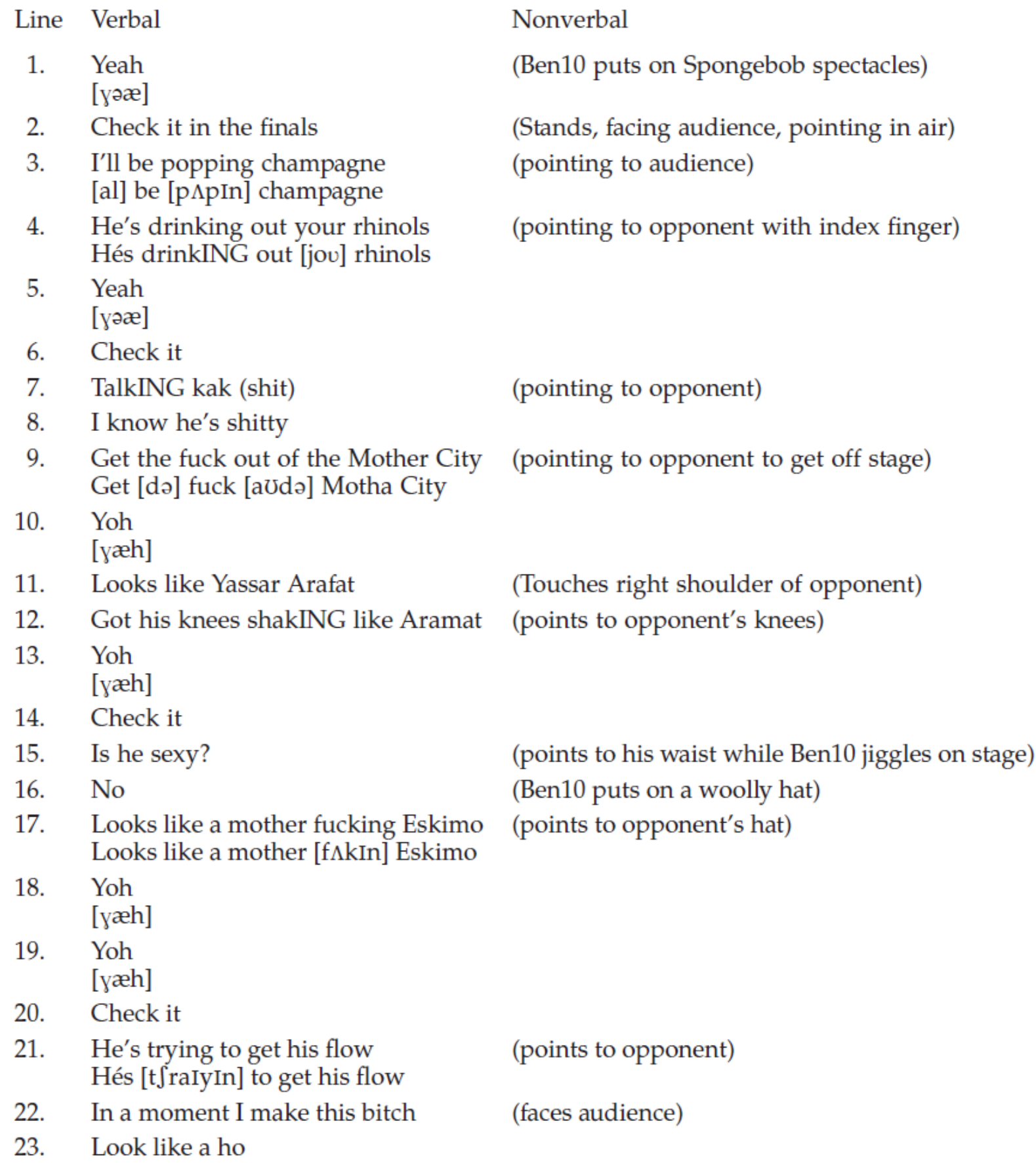

As his lyric unfolds, his South African mix of local English and Kaaps becomes increasingly saturated with insertions of stereotypical elements from African American English (AAE). Cutler identifies five such phonological resources in what she refers to as hip-hop speech style: the AAE typically used by White and middle-class youth. These features, which, are undergoing increasing conventionalization are: 1) the absence of the rhotic /r/; 2) monophtongal /ay/, 3) t/d deletion; 4) verbal -s absence, and 5) copula absence. TaktikOne's use of these features is partial and selective; for example, in line 17 the third person singular -s is present and in lines 4, 8, 15 and 21 we find him using the copular. Other features present in his performance are, however, highly emblematic of his New York AAE target style. For example, in lines 1 to TaktikOne uses monopthongal (ah) (I'll) in line 3 and the non-rhoticized /jov/ıpın/ with a mid-central first vowel and an alveolar, not velar nasal /n/, features widely stereotyped as African American English 
(Bucholtz 2011), but also using the high front lax vowel [I] typical of more mid-American English. The vocalized (vowel-like) / $\mathrm{r}$ / in "your" is delivered as (jov) rhinols.7 In line 9, we again see a clustering of typical AAE features, namely fortition of the voiced interdental fricative /ð/ to a voiced alveolar stop [d] in word initial expressions such as the /də/ and in such phrases such as out of the as [avdə] (line 9). While the fortition of the voiced alveolar stop [də] occurs only once, it complements the shift between the palatals Yeah (уəæ) and Yoh ( $\mathrm{x}$ æh) respectively. There is also an in/ING alternation, with ING on lines 4, 7, 9 and 12 vs /In/ on lines 3, 17 and 21; again displaying a partial and selective use of AAE features.

These features occur together with a familiar feature of global hip-hop freestyle rap battling, namely verbal cues, such as "Yoh" and "Uh" that serve to organize lyrical content, cadence and flow in freestyle rap performing. In TaktikOne's opening moves, verbal cueing features a number of times (lines, 1, 5, and 6), and creating the impression of allegiance to "global rap."8 However, there is no evidence here of AAE morphology (note for example the presence of the copula (line 21), the full pronunciation of "I'll," (line 3) and the use of third person singular -s (lines 11 and 17). We also see him using some limited Kaaps lexis (for example "kak," translated as talking shit on line 7).

Although our White emcee appears initially to struggle in formulating content to maintain his cadence, he nevertheless eventually settles on the lexical pair Yoh and Eskimo to construct a rhyme that allows him to pursue the battle objective of emasculating his opponent. Here, indexicalities of race such as AAE begin to intersect with indexicalities of class, gender and sexuality (e.g., Bucholtz 1999; Chun 2001, 2004, 2009; Cutler 2003; Gaudio 2001; Goodwin and Alim 2010; Mendoza-Denton 2008). This is clear in the following round, where TaktikOne questions the Coloured emcee Ben10's masculinity in a series of rhymes that present his protagonist as sexually preoccupied, but unsuccessful in impressing a partner.

\section{Transcript 2:}

$\begin{array}{lll}\text { Line } & \text { Verbal } & \text { Nonverbal } \\ \text { 1. } & \begin{array}{l}\text { Yeah } \\ \text { [yææ] }\end{array} & \\ \text { 2. } & \begin{array}{l}\text { I know he got his boy's cock in } \\ \text { I know he gots his boy's [kek] in }\end{array} & \begin{array}{l}\text { (pointing to audience, pointing to his } \\ \text { penis) } \\ \text { (pointing to his penis) }\end{array} \\ \text { 3. } & \begin{array}{l}\text { And he tied his feet and he's cocking } \\ \text { And he tied his feet and he's [kekING] }\end{array} & \text { (pointing to opponent's eyes) } \\ \text { 4. } & \begin{array}{l}\text { You know his eyes is locking } \\ \text { You know his eyes is [lekING] }\end{array} & \text { (pointing to own eyes) } \\ \text { 5. } & \begin{array}{l}\text { Trying to think of some shit } \\ \text { [t } \int \text { raIyIn] to think of some shit }\end{array} & \\ \text { 6. } & \text { But I'm shockING } & \text { (pointing to opponent) } \\ \text { 7. } & \text { Oh } & \text { Now he's touching himself }\end{array}$

His sharp accusation of Ben10's lack of tough masculinity is clear recognition of the high value conferred on such a form of manhood, "a particular type of street-wise, ghettocentric, masculine, heteronormative blackness" (Alim, Lee, and Carris 2010:129) that figures prominently in American rap and its translocal derivatives. However, 
TaktikOne is not only intent on emasculating his opponent and showcasing his prowess in performing global rap, he is also using linguistic forms typical of AAE (such as "gots" in line 2 above to express what is covered in the modal verb "have"/ "have to"; the lack of third-person agreement in line 4, and g-dropping in line 5) as well as the content of Black masculinity to present himself as hypermasculine (Bucholtz 1999:453; Bucholtz and Lopez 2011; Chun 2009). We perceive this in the following sequence, where the audience reacts negatively to TaktikOne's hypermasculine presentation by racing the stage, and attempting to force money into his pocket. In doing so, they refuse his hypermasculine stance and in fact gender him as female; specifically, as a stripper in a nightclub. The significance of the audience's response on the stage, is made explicit by TaktikOne in the continuation of his lyrics in Transcript 3 below, from lines 1-8.

\section{Transcript 3:}

\begin{tabular}{|c|c|c|}
\hline Line & Verbal & Nonverbal \\
\hline 1. & $\begin{array}{l}\text { Yeah } \\
\text { [үәæ] }\end{array}$ & \\
\hline 2. & And I don't like you takING pictures & $\begin{array}{l}\text { (audience member tries to put money in } \\
\text { TaktikOne's pocket) }\end{array}$ \\
\hline 3. & Check it & $\begin{array}{l}\text { (The Freestyle mediator intervenes to take } \\
\text { the money and pushes the audience } \\
\text { member off stage) }\end{array}$ \\
\hline 4. & He's already one of my bitches & (points to opponent) \\
\hline 5. & $\begin{array}{l}\text { Yoh } \\
\text { [yæh] }\end{array}$ & \\
\hline 6. & This guy thinks I'm a strippa & $\begin{array}{l}\text { (points to audience member who give } \\
\text { money to him) }\end{array}$ \\
\hline 7. & Get the fuck off the stage & $\begin{array}{l}\text { (points to audience member who give } \\
\text { money to him) }\end{array}$ \\
\hline 8. & This guy's gooing lippe & $\begin{array}{l}\text { (points to opponent) (Ben10 gesturing to the } \\
\text { audience to stay off-stage) }\end{array}$ \\
\hline
\end{tabular}

He delivers his lyrics calmly with some jocularity, countering the attack with phonological features of AAE (for example, "I'm a strippa," line 6), where we again notice the use of postvocalic /r/-lessness. In the same utterance, we also find an example of an English-Kaaps code-switch (in lyric 8) with the verb "gooing," which is a combination of gooi in Afrikaans plus the angma ing alongside "lippe" (talking in Afrikaans). These features are typically found in the speech of Kaaps speakers who speak English as a second language (McCormick 2002).

To this pool of features from Kaaps, AAE and British English (see endnote 7), TaktikOne adds some salient and typifying phonological and lexical features of White South African English (WSAfE), such as the strengthening of the phonological variant $/ \mathrm{j} /$ to $/ \mathrm{\gamma} /$ raised before a mid-central vowel (уәæ) (see line 1 above) and the palatalization of the mid-back vowel in ( $\mathrm{x}$ æh) (line 5 above) to his (frequent) use of hip-hop verbal cues like "Yeah" and "Yoh" (Bowerman 2008; Lash 2002). Together with the lexical choices already mentioned, such as lippe (in Afrikaans, translated as lips in English) and gooing ("going" in South African English), we see TaktikOne moving his rhymes across a 
complex market of features, appropriating linguistic features across racial and geopolitical boundaries.

So far, it is clear that TaktikOne is playing the game as it should be playedpositioning himself within a certain genre of global rap, emasculating his opponent and sculpting a persona for himself as hypermasculine and hypersexual, while "dissing" his opponent as massively lacking in these regards. The uses of salient markers of AAE and verbal cues profile TaktikOne as a proficient and savvy rapper, skillful at deploying recognized features of high-end performance rap. His strategy is familiar from other rappers who bolster their street credibility by aligning "themselves semiotically closer to the urban ghetto [and] by obscuring the racial and class boundaries that separate them from the urban African American community" (Cutler 2003:215). However, looking closely at how the battle unfolds and becomes reframed in the rhymes of his contestant, Ben10, it becomes evident that TaktikOne can also be seen as concurrently relocating his whiteness out of a South African space and into a transnational arena while simultaneously being seen as asserting a hegemonic White advantage in prowess, competence, and rap proficiency. Ben10's response also shows that TaktikOne can be perceived as reinforcing a White hegemony at the same time as his whiteness becomes invisibilized (through being linked to proficiency in the rap genre).

Ben1o is a multilingual emcee from Paarl hip-hop community predominantly influenced by U.S. West Coast hip-hop. He has an aggressive and comedic hip-hop style, with a cadence and flow that bear a resemblance to gangsta rap. In his performance, he chooses to step away from the use of English with its associations with more conventional American rap by rapping in Kaaps. This has the effect of not only challenging his opponent linguistically but also of framing the freestyle battle space as a racially contested space. Ben10 focuses his lyrics on the socioeconomic mediation of class linked to Kaaps and the Coloured body, rather than sexuality per se. That is, class, the socioeconomic body, tough masculinity, and place are all interrelated factors in the specifically South African-entextualized discourses of race. Ben10's complaints target what he perceives to be TaktikOne's attempts to relocate or remove himself from the space of whiteness.

Ben10 proceeds to unfold his argument: With the spatial backdrop of Cape Town "rap hall” giving precedence to (working-class) Colouredness, Ben1o begins to assign various subject positions (Jaffe 2009:8) to TaktikOne in acts of "transmodal stylization" (Goodwin and Alim, 2010). The first "battle" Ben1o taps into is the way in which the apartheid government manufactured Coloured people as workers in its political economy and the response elicited to this by the "authentic working-class coloured," the tough men of the Cape underworld and Number gangs (Haupt 2001:173; Steinberg 2004). ${ }^{9}$ Framed against the background of the historical tropes of Gamtaal as resistance to White supremacy and his own working-class masculinity, Ben1o starts by responding to TaktikOne's emasculating challenge by in turn denigrating the masculinity of his opponent (e.g., line 3 below, "tax" means to solicit sex from the sister). 


$\begin{array}{lll}\text { Line } & \text { Verbal } & \begin{array}{l}\text { Nonverbal } \\ \text { (takes off and holds a woolie hat in his } \\ \text { hand) } \\ \text { (faces the audience, points to opponent) } \\ \text { I take off my hat }\end{array} \\ \begin{array}{l}\text { Ek het vi' julle in jul tuin gewe'k } \\ \text { I worked in your garden }\end{array} & \begin{array}{l}\text { Maar ek tex jou sissie } \\ \text { But now I tax your sister }\end{array} \\ \text { (faces the audience, points to opponent) } \\ \text { Vi' su'kke shit het ekkie lussie }\end{array} \quad \begin{aligned} & \text { (faces the audience, points to opponent) } \\ & \text { I don't like this shit }\end{aligned}$

Ben10's point of departure here is thus to draw attention to his "working class," laboring experiences, in this case as a gardener for the "generic" baas (master), here personified as his opponent as he literally indexes TaktikOne with his pointing finger. The indexicality of the image of the baas and worker relationship, also read here as Coloured people working for White people, is introduced as an indictment of (the memory of) whiteness and the unequal and exploitative power relations existing between Coloured people and Whites during apartheid. It is notable that Ben1o at this stage of his lyrics refrains from directly and explicitly racializing the relationship, comfortable in the assumption that his audience will understand this past economic inequality as a racial one. Ben1o is thus building a persona associated with local ideologies of race around working bodies and power hierarchies, in relation to the "white baas." Once racializations are framed with reference to tropes of working bodies, a space is opened up for Ben10 to assert his masculine dominance by alluding to his "taxing" of TaktikOne's sister in a clear reference to the subjugation of the body of the White woman by nonwhites, one of the great fears of the White apartheid mind.

This is an explicit inversion of the racialized power to dominate bodies, moving from the historical obligation of "the coloured body" to work for the master, to the proposition in Ben10's lyrics of the White body (female) working for the Coloured male. By introducing a critique of whiteness through a critique of the masculinity and sexuality of his opponent, Ben10 challenges traditional forms of racializations in an attempt to one-up his opponent. However, in doing so, Ben10 makes explicit reference to race in what seems to be a move to a new kind of freestyle rap.

That is, he goes beyond rapping to assert his toughness and masculinity, explicitly engaging with "white privilege" by conducting a local, interactionally accomplished inversion of hegemonies of race by embedding his rhyme in racial jibes on TaktikOne's "whiteness" and its historical significance. In the following segment, Ben1o brings into operation various identity features of Coloured identity as historically linked with whiteness, even though his opponent doesn't mention nor acknowledge the obviousness of race. In the following three lines, Ben 10's freestyle battle performance draws on linguistic and intertextual features of how his body and TaktikOne's body were, and still are, largely perceived in South African minds. His comments reflect upon the differential aesthetics of the body-techniques of the self or sensory regime (Roth-Gordon 2007, 2012)-that differentiate(d) Whites and Coloureds/Blacks. 


$\begin{array}{lll}\text { Line } & \text { Verbal } & \text { Nonverbal } \\ \text { 1. } & \begin{array}{l}\text { Ek sien jou hare is spikey } \\ \text { I see your hair is spikey }\end{array} & \text { (faces the audience, points to opponent) } \\ \text { 2. } & \begin{array}{l}\text { Ek is maar n fokken taai kop laaitie } \\ \text { I'm just a fucking nappy head kid }\end{array} & \text { (touches his head) } \\ \text { 3. } & \begin{array}{l}\text { Ek se jou dai was nog 'ie tight 'ie } \\ \text { I tell you those rhymes wasn't tight }\end{array} & \text { (points into audience) }\end{array}$

Ben10 does not use many expletives or other linguistic features of aggression to perform his body and bodily stance, although he does make a number of intertextual references to emasculate the assumed toughness of his opponent. For instance, the Kaaps linguistic techniques used by Ben1o evokes the trope of the (un)disciplined body (Roth-Gordon 2011:212) of Coloured people that circulated in the discourse and sensibilities of White South Africans during apartheid. Kaaps as "bad language" is resemiotized and inverted in the freestyle battle space. The challenge laid against his White opponent's body, as the lyrics attest, is an attempt by the emcee to "racially transform" his body by deliberately drawing on figures of tough men and his White opponent's perceived desire to claim or secure-even if temporarily-the culinity associated with a proficient rap performance. As he argues lyrically, TaktikOne is:

\section{Transcript 6:}

Line Verbal

1. Soes Magnito

Like Magnito

2. Djy't $\mathrm{n}$ metaal belt

You've got a metal belt

3. Maa' ek lug jou op soes Don Vito

But I pick you up like Don Vito

4. En soes perlemoene And like abalone
Nonverbal

(takes two steps back)

(points to opponent's metal belt)

(Taktik turns sideways and yawns)

(gestures simultaneously with his left hands)

5. Wanee' kom Whiteys uit met gruis handskoene? When will Whiteys come out and help with their grey gloves?

In these lines, Ben1o associates TaktikOne with a fictive superhero (Magnito in X-men) identity which he trumps, figured as the Mafioso Don Vito. The reference to abalone has both historical and contemporary significance, since Coloured people have historically lifted crates of abalone by the sea (line 4). In line 5, Ben10 uses "Whitey," the term commonly used by Kaaps speakers to describe Whites. In another instance of power inversion, he evokes a potential day in the post-apartheid South Africa, when Whites will become the laborers (helping with their gray gloves) along- side Coloureds.

This dethroning of racial privilege in tropes of the working class body is further elaborated in Ben1o's depiction of the very real entanglements, in historical time and today, between Coloured and White bodies. In contrast to TaktikOne's performative strategies of indirectness and racial avoidance in the battle through African American 
English, the response by Ben1o destabilizes (from lines 1 to 7 below), with the help of the audience, the certainty and dominance of his opponent's local whiteness.

\section{Transcript 7:}

Line Verbal

1. Nai, ek sien hy's Navy blue Nah, I see he's Navy blue

2. But hy's soe wit soes Diamond White But he's so white like Diamond White

3. Sy bestaan is te danke aan die Tuin boy His existence is thanks to the Garden Boy

4. Want sy ma was te jas vir Marmite 'Cause his mother had a craving for Marmite

5. That's why

6. Ek was die Whitey met Sunlight ${ }^{10}$ I wash this Whitey with Sunlight

7. En dai's o'right And that's alright
Nonverbal

(moves into spotlight)

(points the bright white spotlight on the roof)

(moves to the edge of the stage)

(points to the audience)

Audience Members: Laughs!

(points to opponent)

(points to audience)

Race is operationalized indirectly in lines 1 to 4 , through references to "navy blue," "Diamond White" and "Marmite." The word navy blue here refers to the colour of the spotlight on TaktikOne. Ben10 uses the spotlight to compare his opponent's whiteness to being almost navy blue-meaning, almost Coloured or Black - but if he and the audience look closely and inspect further, TaktikOne is actually as White as a bright, "Diamond White." Marmite is a popular breakfast spread made out of yeast extract that has a strong black color; Ben1o evokes, in line, 4 TaktikOne's mother's fondness for Marmite as an indirect reference to her sexual attraction to the garden boy, mentioned in line 3 . We note here how Ben1o represents TaktikOne as not fully biologically White but as an offspring of an interracial encounter. Roth-Gordon (2011) notes White bodies are often "defined by their 'natural' proclivity to discipline and their capacity for refinement and control, in contrast to non-white bodies, where tendencies to excessive consumption are seen as grounded in "uncontrollable violence, lack of personal hygiene" (Roth-Gordon 2011:212). She further suggests that racializations are not determined by color alone, and that sloppy, poor, disavantaged whites may lose their whiteness because, citing Heneghan, even though "one might have been born with a biological white- ness, and earn or inherit it in the upper class goods delimiting class, and display it upon the body, and throughout the house, but one also had to maintain it, clean it and polish it and take care not to break it-in order to truly achieve whiteness" (Roth-Gordon 2011:213 citing Heneghan 2003:132).

In this case, TaktikOne's erasure of race has been undermined by Ben1o's introduction of entanglements of the historical and contemporary body, and his hammering home of race as a demarcated battleground in this interaction. Ben10 accomplishes are-indexicalization of whiteness, where the emphasis is on the agency of Ben1o himself to determine the "true" racial meaning of the white boy as he "washes him white." This is an interesting reversal of how discourses of linguistic and bodily discipline were historically used in regimenting non-whites (Roth-Gordon 2011). At the same time, the avoidance of 
English and the preference for Kaaps in Ben10's rendition saves him from the danger of being "deracialized," and therefore, vulnerable to being positioned in TaktikOne's lyrics in terms of (lack of) tough masculinity.

At this juncture, TaktikOne recognizes that any attempt he might wish to make to disrupt or reorganize the racial normativities of the local hip-hop freestyle is doomed to failure, as he complains to the audience by way of concluding:

\section{Transcript 8:}

\begin{tabular}{|c|c|c|}
\hline Line & Verbal & Nonverbal \\
\hline 1. & This guy wouldn't get investigated & (points to opponent) \\
\hline 2. & If his name was Julius ${ }^{11}$ & (points to opponent's face) \\
\hline 3. & Stop looking at him like you ø curious & (moves a pace forward to front stage) \\
\hline 5. & Yoh & \\
\hline 6. & I wish I was a little bit darka & (steps back and points to opponent) \\
\hline 7. & Then I get some love in this club & \\
\hline 9. & Yoh & (shuffles nervously on stage) \\
\hline 10. & Where's that cat Barka? ${ }^{12}$ & Audience Members: Booh! \\
\hline 11. & Yoh & \\
\hline 12. & Give me some boohs & (points at audience) \\
\hline 13. & You know I love it & \\
\hline 14. & Yoh & \\
\hline 15. & Fuck it. & Audience Members: Booh! \\
\hline
\end{tabular}

Throughout the Coloured emcee's performance, we note then, a firm predilection for a racially focused thrust that brings out the entanglement of race with class and history. Ben10's performance is a process of deauthentification of his opponent as he simultaneously deconstructs the boundary between racialized and class-based groups. The types of indexicalizations of race, sexuality and labor, and the personae linked to this rap battle are clearly the outcome of specifically South African categories of race and class, as well as the historical entanglements of peoples, and ultimately of the sociopolitical circumstances of the larger part of the South African population itself.

\section{Discussion and Conclusion}

Alim et al. have explored how hip-hop artists make use of racial and ethnic stereo- types as "a resource in responding to the moment-to-moment challenges of winning a battle" (2010:116), and how these battles are in themselves "constitutive of larger sociological processes of race, class and gender" (Alim et al. 2010:116). They note the ways in which the lyrical orchestration of conflict provides the space to negotiate local meanings of race, and to "invert dominant meanings attached to racial and ethnic identities" while "ultimately work[ing] to maintain them" (Alim et al. 2010:117). This is what we find in the freestyle battle analyzed here. The battle unfolds away from a superficially more "conventional" rap thematics centered on tough masculinities to become a contest on the meaning of whiteness, pivoting significantly around competing constructions of whiteness, phrased in transnational versus transtemporal tropes. More specifically, we saw how our "white rapper" through his use of iconic features of "blackness," attempted to establish his 
hypermasculinity and thereby also his proficiency in the genre. TaktikOne, employed fragments (or gestures) of Kaaps and South African and British English inserted into an African American English (AAE) frame, reinforcing the idea that African American (hiphop) culture pivots around "a heterosexual, male urban street culture" (Chun 2001:56). However, Ben10's repartee shows that he perceives TaktikOne's use of indices of AAE as going beyond merely appropriating indices of Blackness to perform a ghettoized hypermasculinity. Ben1o's performance attributes intentionality to TaktikOne: specifically, that TaktikOne is "doing black" in order to indulge in racializations of transnational or unmarked whiteness that make that whiteness invisible. Ben1os tactic finds a rationale in the way in which features of AAE have become re-indexicalized through global spread as performance features of the genre (Bucholtz and Lopez 2011; Chun 2009). In other words, because TaktikOne is using features of AAE to present himself as a proficient lyricist and skillful rapper the blackness and its associations through hypermasculinity are downplayed, allowing an appropriation by white rappers as yet another "colourless" currency. This is the significant punch that Ben10 delivers, namely to point out this other layer of indexicalisation, namely how competence and proficiency in the local South African context is unconsciously associated with whiteness. This means that markers of prowess, in this case, AAE, are thereby open to white appropriation as markers of whiteness. We are reminded of Roth- Gordon's note on how White speakers' use of Mock Spanish in shifting in and out of whiteness accrue the opposing positive values of whiteness and nonwhiteness, while still maintaining a system of racial difference that includes the assertion of white superiority and the continued disenfranchisement of people of color. (Roth-Gordon 2011:223)

This appears to be what Ben10 is reacting to when he aggressively orientates his rhymes toward highlighting the racial implications in TaktikOne's performance, which Ben1o characterizes as almost "false claims" to Whiteness. By racializing the battle, Ben1o flags this parallel undercurrent and reframes the rules of engagement to be the racialization of masculinity. He is thus outing the "invisible Whiteness" in TaktikOne's performance, and at the same time, repositioning TaktikOne as a specifically local South African White (who is performing a transnational White) with all its historical entanglements. He does this by refusing his opponent's rap authenticity, by ignoring TaktikOne's translocally situated rhymes, introducing instead historical tropes, or transtemporal narratives and intertextualities with earlier racializations to recontextualize and reinterpret the significance of TaktikOne's tropes of whiteness.

TaktikOne's unsuccessful attempts at deliberate nonengagement with race as a visible category of contestation, reinforces the unmarked status of whiteness, "reinscribe/ing/ the deeply problematic dichotomy between rational middle-class whiteness and physical working-class blackness and, thus, reinforces essentialized boundaries between racialized and class based groups" (Bucholtz and Lopez 2011:702). This is also highlighted in Ben10's contestation when he lifts forth the Coloured working-class body and insists on TaktikOne's historical entanglement with these bodies. The erasure of particular forms of whiteness generally, can in itself be seen as a potentially aggressive act by many interlocutors, as it denies explicit management or engagement with an important dimension of power, the power to retain the "unchallenged" or assumed privilege to determine the unmarked or normative order. Thus, not mentioning 
Whitenesss, or Whites themselves "determining" the "meaning" of Whiteness could easily be perceived as a subtle exercise in the symbolic denigration of the other-an invisibilization of features of racially based power. The unmarked nature of whiteness is particularly insidious in this case, as it is also intimately linked to competent and authentic performances, and prowess in the genre of hip-hop, reminding us of how South African Whites claim competence against a tableau of lesser competence in Blackness. It is precisely here that the power of Whiteness lies (Trechter and Bucholtz 2001:5), in suggesting (indirectly) that other racialized groups may not be as astute (Bucholtz 2011:15; cf. Chun 2009).

Shome (2000:367) asks, "how the everyday organization of social and cultural relations function to confer benefits and systemic advantage to whites?" In contemporary South Africa, Whiteness remains to a large extent "a power-laden, discursive formation that privileges, secures and normalizes the cultural space of the white Western subject" (Shome 1999:108). From the analysis, we see that Whiteness secures "its hegemonic everyday-ness, its violent normativity" (Shome 2000:367) in an important sense, through the semiotic significance accorded to the genre-specific features, tropes and routines of American rap. It is this that allows TaktikOne to comfortably enact an unmarked, transnational or transportable Whiteness, affirming Shome's point that Whiteness travels with ease across translocal spaces, carried by "cultural products" (such as texts, rap tropes, and the like) that legitimize and reproduce it as the unmarked case found anywhere and everywhere (Alexander 2013; Shome 2000). We see here the unique affordance that performance genres of this type provide Whiteness to protect itself, shift location, change shape, and seem to all but disappear (Durrheim et al. 2011). And although Whiteness may be finally revealed in the harsh light of "racialized outing," as in the battle between TaktikOne and Ben1o, this only serves to reinforce the salience of Whiteness as a fundamental framing of the battle. By acknowledging-and vehemently refusing to accept-TaktikOne's claims to transnational Whiteness, the legitimacy of Whiteness and the racialized status quo is reproduced. 


\section{Notes}

Acknowledgement. This work was fully supported by the Flemish Interuniversity Council (VLIR-DBBS, UWC), and partly supported by the Max Planck Institute for Religious and Ethnic Diversity, the Research Council of Norway's (RCN) Yggdrasil funding scheme, project number 227492/F11, and its Centres of Excellence funding scheme, project number 223265. This work was fully supported by the Flemish Interuniversity Council (VLIR-DBBS, UWC), and partly supported by the Max Planck Institute for Religious and Ethnic Diversity, the Research Council of Norway's (RCN) Yggdrasil funding scheme, project number 227492/F11, and its Centres of Excellence funding scheme, project number 223265 .

1. See Hendricks 2012; Dyers 2008:52; and Prah 2012 for a debate on mainstreaming Afrikaans and the focus on its varieties.

2. The word Gam in Gamtaal refers to Ham, the cursed son of Noah (see Mesthrie 2008; Battersby 2003:114).

3. By global hip-hop we mean, the historical, cultural and linguistic process that involves the decontextualization, recontextualization and 'relocalization' of hip-hop cultures in various localities across the world (Androutsopolous 2009; Pennycook 2012) from its earliest forms in the Bronx, New York,.

4. Although hip-hop and Coloured identity was traditionally articulated predominantly through the use of Gamtaal, we have to point out that today Cape Town rap performances are increasingly multilingual (see Haupt 1996; Warner 2007).

5. Downloaded from http://www.youtube.com/watch?v=JMjN1385DrU (uploaded by DJeFx; Accessed December 3, 2012).

6. It should be noted that on the night of the battle, no Coloured female emcees performed on stage, except for one White female emcee. Further, to our knowledge, only Coloured emcees have won the coveted freestyle battle prize. In 2009, this prize went to a coloured Emcee-Cole or Cola-and thereafter (in 2010) to Hemelbesem (also a Coloured Emcee). We make reference here to the racial identity of the 2009 and 2010 Freestyle Battle champions because as we will demonstrate shortly, most Coloured emcees are brought up into rhyming in Kaaps and English.

7. One would have expected this pronounciation to be more of an approximation to [ju], the realization as joo we suspect may be due to this performer's British English background.

8. In South Africa, historically, and even today, hip-hop is a Coloured space but the thematics of Hip-Hop (urbanism, working class, etc.) often mimics the situation of the Blacks in the United States more than the Blacks in South Africa did) (Warner 2011).

1. The Number gangs are infamous prison gangs in South Africa. They are comprised of the $26 \mathrm{~s}, 27 \mathrm{~s}$, and $28 \mathrm{~s}$.

2. Sunlight is a type of washing powder used in South African households.

3. The name Julius here refers to the ousted rabble-rouser but now-defunct African National Congress (ANC) Youth League president Julius Malema who is alleged to have manipulated government tenders to fund his lavish lifestyle.

4. The name Barka (African Americanized here) is the name of a character in the popular television South African soap opera Isidingo (The Need): Barker Haynes. 


\section{References}

Adhikari, Mohamed

2005 Not White Enough, Not Black Enough: Racial Identity in the South African Coloured Community. Athens: Ohio University Press.

2006 Hope, Fear, Shame and Frustration: Continuity and Change in the Expression of Coloured Identity in White Supremacist South Africa, 1910-1994. Journal of South Africa Studies 3(3):467-487.

Alim, H. Samy, Jooyoung Lee, and Lauren Mason Carris

2010 "Short Fried-Rice-Eating Chinese MCs" and "Good-Hair-Havin Uncle Tom Niggas": Performing Race and Ethnicity in Freestyle Rap Battles. Journal of Linguistic Anthropology 20(1):116-133.

2011 Moving the Crowd, 'Crowding' the Emcee: The Coproduction and Contestation of Black Normativity in Freestyle Rap Battles. Discourse \& Society 22(4):422-439.

Alexander, Neville 2013 Thoughts on the New South Africa. Johannesburg: Jacana Press.

Ariefdien, Shaheen, and Marlon Burgess

2011 Putting Two Heads Together: A Cross-Generational Conversation about HipHop in a Changing South Africa. In Native Tongue: An African Hip-Hop Reader. P. K. Saucier, ed. Pp. 219-252. Trenton: Africa World Press.

Androutsopolous, Jannis

2009 Language and the Three Spheres of Hip-Hop. In Global Linguistic Flows: Hip-Hop Cultures, Youth Identities, and the Politics of Language. H. S. Alim, A. Ibrahim, and A. Pennycook, eds. Pp. 79-95. London: Routledge.

Battersby, Jane

2003 Sometimes It Feels Like I'm Not Black Enough": Recast(e)ing Coloured through South African Hip-Hop as a Postcolonial Text. In Shifting Selves: PostApartheid Essays on Mass Media, Culture and Identity. H. Wasserman and S. Jacobs, eds. Pp. 109-129. Cape Town: Kwela Books.

Bauman, Richard

2005 Commentary: Indirect Indexicality, Identity, Performance, Dialogic Observations. Journal of Linguistic Anthropology 15(1):145-150.

Bekker, Ian

2012 The Story of South African English: A Brief Linguistic Overview. IJLTIC 1(1):139-150.

Blignaut, Joline

2014 n Ondersoek na die Taalgebruik in die Son as Verteenwoordigend van Kaapse Afrikaans. Unpublished master's thesis, Stellenbosch University, Stellenbosch.

Bowerman, Sean

2008 White South African English: Phonology. In Varieties of English, 4: Africa, South and Souteast Asia. Rajend Mesthrie, ed. Pp. 931-942. Berlin: Mouton de Gruyter.

Bucholtz, Mary

1999 You Da Man: Narrating the Racial Other in the Production of White Masculinity. Journal of Sociolinguistics 3(4):443-460.

2011 White Kids: Language, Race and Styles of Youth Identity. Cambridge: Cambridge University Press. 
Bucholtz, Mary and Quiana Lopez

2011 Performing Blackness, Forming Whiteness: Linguistic Minstrelsy in Hollywood Film. Journal of Sociolinguistics 15(5):680-706

Chun, Elaine

2001 The Construction of White, Black, and Korean American Identities through frican American Vernacular English. Journal of Linguistic Anthropology 11:52-64.

2004 Ideologies of Legitimate Mockery: Margaret Cho's Revoicings of Mock Asian. Pragmatics 14:236-289.

2009 Speaking Like Asian Immigrants: Intersections of Accommodation and Mocking at a U.S. High School. Pragmatics 19:17-38.

Coupland, Nikolas

2009 Style: Language Variation and Identity. Cambridge: Cambridge University Press.

Cutler, Cecilia

2003 "Keeping It Real": White Hiphoppers' Discourses of Language, Race, and Authenticity. Journal of Linguistic Anthropology 13(2):211-233.

2009 “You Shouldn't Be Rappin', You Should Be Skateboardin' X Games": The Construction of Whiteness in an MC Battle. In Global Linguistic Flows: HipHop Cultures, Youth Identities, and the Politics of Language. H. S. Alim, A. Ibrahim, and A. Pennycook, eds. Pp. 79-95. London: Routledge.

Dolby Nadine E.

2001 Constructing Race: Youth, Identity, and Popular Culture in South Africa. New York: State University of New York Press.

Durrheim, Kevin, X. Mtose, and L. Brown

2011 Race Trouble: Race, Identity, and Inequality in Post-Apartheid South Africa.

Durban: University of Kwazulu-Natal.

Dyers, Charlyn

2008 Language Shift or Maintenance? Factors Determining the Use of Afrikaans among Some Township Youth in South Africa. Stellenbosch Papers in Linguistics 38:49-72.

Erasmus, Zimitri

2005 Race and Identity in the Nation. In State of the Nation: South Africa 20042005. J. Daniel, R. Southall, and J Lutchman, eds. Pp. 9-34. Cape Town and East Lansing: HSRC Press and Michigan State University Press.

Erasmus, Zimitri, ed.

2001 Coloured by History, Shaped by Place: New Perspectives on Coloured Identities in Cape Town. Cape Town: Kwela Books.

Gabriel, John

1998 Whitewash: Racialized Politics and the Media. London: Routledge.

Gaudio, Rudolf

2001 "White Men Do It Too": Racialized (Homo)sexualities in Postcolonial Hausaland. Journal of Linguistic Anthropology 11(1):36-51.

Goodwin, Marjorie and H. Samy Alim

2010 "Whatever (Neck Roll, Eye Roll, Teeth Suck)": The Situated Coproduction of

Social Categories and Identities through Stancetaking and Transmodal. Journal of Linguistic Anthropology 20(1):179-194. 
Haupt, Adam

1995 Rap and the Articulation of Resistance: An Exploration of Subversive Cultural Production during the Early 90s, with Particular Reference to Prophets of Da City. Unpublished master's mini-thesis, Department of English, University of the Western Cape, Bellville, South Africa.

1996 Stifled Noise in the South African Music Box: Prophets of Da City and the Struggle for a Public Space. South African Theatre Journal 10(2):51-61.

2001 Black Thing: Hip-Hop Nationalism, 'Race' and Gender in Prophets of Da City and Brasse vannie Kaap. In Coloured by History, Shaped by Place: New Perspectives on Coloured Identities in Cape Town. Z. Erasmus, ed. Pp. 172-194. Cape Town: Kwela Books.

Hendricks, Frank

2012 Iluminating the Neglected: A View on Adam Small's Literary Integration of Kaaps. Tydskrif vir Letterkunde 49(1):95-114.

Heneghan, Bridget T.

2003 Whitewashing America: Material Culture and Race in the Antebellum Imagination. Jackson: University Press of Mississippi.

Jaffe, Alexandra

2009 Introduction: The Sociolinguistics of Stance. In Stance: Sociolinguistic Perspectives. A. Jaffe, ed. Pp. 3-28. Oxford: Oxford University Press.

Lash, Roger

2002 South African English. In Language in South Africa. R. Mesthrie, ed. Pp. 104-126. Cambridge: Cambridge University Press.

Lee, Jooyoun

2009 Battlin' on the Corner: Techniques for Sustaining Play. Social Problems 56/3:578-598. Marx, Hannelie, and Viola Candice Milton

2011 Bastardized Whiteness; 'zef'-culture, Die Antwoord and the Reconfiguration of Contemporary Afrikaans Identities. Social Identities 17(6):723-745.

McCormick, Kay

2002 Language in Cape Town's District Six. Oxford: Oxford University Press. Mendoza-Denton, Norma

2008 Homegirls: Symbolic Practices in the Making of Latina Youth Styles. Oxford: Blackwell.

Mesthrie, Rajend

1992 English in Language Shift: A History Structure and Sociolinguistics of South African Indian English. Johannesburg: University of Witwatersrand Press.

2008 "I’ve Been Speaking Tsotsitaal All My Life without Knowing It": Towards a Unified Account of Tsotsitaals in South Africa. In Social Lives in Language. M. Meyerhoff and N. Nagy, eds. Pp. 95-109. New York: Benjamins.

Pennycook, Alastair

2012 Language and Mobility: Unexpected Places. UK: Multilingual Matters.

Prah, Kwesi Kwah

2012 Mainstreaming Afrikaans: Regional Varieties. Cape Town: CASAS.

Roth-Gordon, Jennifer

2007 Racing and Erasing the Playboy: Slang, Transnational Youth Subculture, and Racial Discourse in Brazil. Journal of Linguistic Anthropology 17(2):246-265. 
2011 Discipline and Disorder in the Whiteness of Mock Spanish. Journal of Linguistic Anthropology 12(2):211-229.

2012 Linguistic Techniques of the Self: The Intertextual Language of Racial Empowerment in Politically Conscious Brazilian Hip-Hop. Language and Communication 32:36-47.

Shome, Raka

1999 Whiteness and the Politics of Location. In Whiteness: The Communication of Social Identity. T. K. Nakayama and J. N. Martin, eds. Pp. 108-122.Thousand Oaks: Sage Publications.

2000 Outing Whiteness. Critical Studies in Media Communication 17:368. Small, Adam

1972 Adam Small in Gesprek met Ronnie Belcher. In Gesprekke met Skrywers 2. Pp. 93-105. Kaapstad, Johannesburg: Tafelberg-Uitgewers.

1987 Kitaar my kruis. Derde, Hersiene Uitgawe. Pretoria: HAUM-Literêr

Steinberg, Jonny

2004 The Number: One Man's Search for Identity in the Cape Underworld and Prison Gangs. Johannesburg: Jonathan Ball.

Steyn, Melissa

2004 Rehabilitating a Whiteness Disgraced: Afrikaner White Talk in PostApartheid South Africa. Communication Quarterly 52(2):143-169.

Trechter, Sara and Mary Bucholtz

2001 White Noise: Bringing Language into Whiteness Studies. Journal of Linguistic Anthro- pology 11(1):3-21.

Walker, Melanie

2005 Race Is Nowhere and Race Is Everywhere: Narratives from Black and White South African University Students in Post-Apartheid South Africa. British Journal of Sociology of Education 26(1):41-54.

Warner, Remi

2007 Battles over borders: Hip-hop and the politics and poetics of race and place in the new South Africa. Unpublished PhD dissertation. Toronto, Ontario: York University.

Warner, Remi 2011 Colouring the Cape Problem Space: A Hip-Hop Identity of Passions. In Native Tongue: An African Hip-Hop Reader. P. K. Saucier, ed. Pp. 105-146. Cape Town: Africa World Press.

Watkins, Lee

2001 'Simunye, We Are Not One': Ethnicity, Difference and the Hip-Hoppers of Cape Town. Race \& Class 43(1):29-44.

Williams, Quentin and Christopher Stroud

2010 Performance Rap Ciphas in Late-Modern Cape Town: Extreme Locality and Multilingual Citizenship. Afrika Focus 23(2):39-59. 